\title{
Biopesticide and formulation processes based on starch industrial wastewater fortified with soybean medium
}

\author{
Adama Ndao ${ }^{1 *}$, Lalit R Kumar $^{1}$, Rajeshwar.D. Tyagi ${ }^{1}$, Jose Valéro ${ }^{1}$
}

${ }^{1}$ INRS-ETE, Université du Québec, 490, Rue de la Couronne, Québec, Canada GIK 9A9.

\begin{abstract}
The aim of this study was to produce Bacillus thuringiensis based biopesticide using starch producing industry wastewater (SIW) fortified with soybean medium and optimize the formulated product using different adjuvants. This study was necessary as low endotoxin concentration is obtained in formulated biopesticide when SIW alone is used as fermentation medium. The fermentation runs were conducted using SIW alone and SIW fortified with $25 \%$ soybean (w/v) medium in $2000 \mathrm{~L}$ and $150 \mathrm{~L}$ bioreactor respectively. SIW supplemented with soybean medium showed an increase in cell count (from $1.95 \times 10^{8}$ $\mathrm{CFU} / \mathrm{mL}$ to $1.65 \times 10^{9} \mathrm{CFU} / \mathrm{mL}$ ), spore synthesis (from $1.5 \times 10^{8} \mathrm{CFU} / \mathrm{mL}$ to $1.35 \times 10^{9} \mathrm{CFU} / \mathrm{mL}$ ) and endotoxin concentration (from $436 \mu \mathrm{g} / \mathrm{mL}$ to $1170 \mu \mathrm{g} / \mathrm{mL}$ ) when compared to SIW medium alone. The fermented broth was concentrated using continuous centrifugation and adjuvants were added for biopesticide formulation in order to enhance its resistance against UV rays and rainfastness. Entomotoxicity of the formulation produced using fermented broth of SIW fortified with soybean (38000 $\mathrm{IU} / \mu \mathrm{L}$ ) was higher than that obtained by SIW medium alone (21000 IU/ $\mu \mathrm{L})$, commercial biopesticide Foray 76B (20000 IU/ $\mu \mathrm{L}$ ) and Btk sander's (12500 IU/ $\mu \mathrm{L})$.
\end{abstract}

* Corresponding author: 490, rue de la couronne, G1K 9A9, Québec, Canada, Tel: (581) 777-7580; E-mail: adama.ndao@ymail.com

Keywords: Waste management, bacillus thuringiensis var kurstaki, Agroindustrial waste valorization, Entomotoxicity, Fermentation 


\section{Introduction}

The spruce budworm is a devastating and endemic insect pest of North American forests. Its life cycle is one year per generation. After maturation in late fall followed by winter incubation, the $3^{\text {rd }}$-stage caterpillar moves into the foliage of balsam fir or spruce in early spring. This population of caterpillars causes an epidemic every 30 years. Given the importance of the forestry in local economy and the resurgence of the caterpillar population year after year, the fight against this scourge remains crucial. ${ }^{[1,2]}$

Thus, biological control has been undertaken for several years in Canadian forests. Biopesticides based on Bacillus thuringiensis var Kurstaki are the most commonly used to control the problem. ${ }^{[3,4]}$ Btk produces protein crystals made up of delta endotoxin, which bind to the receptors of the larvae's epithelial cells. The epithelial cells are thus destabilized by the creation of transmembrane pores in the cell membrane. The integrity of the epithelial cells is thus affected, leading to paralysis of the larvae's digestive system and the cessation of feeding. At the same time, viable spores produced during the stationary phase of bacterial growth will germinate in the mid gut of the budworm and produce other Btk cells and protein crystals. Proliferation of the bacterium will cause septicemia in larvae and death. ${ }^{[5-8]}$

The advantages of using Btk are numerous: 1) it is highly specific to lepidopteran larvae, certain dipterans and beetles, 2) low persistence after application, 3) and harmless to human and animal health.

${ }^{[6-9]}$ However, the purchase price of substrates for Btk cultivation is a barrier to the competitiveness of Btkbased biopesticides. The raw material cost for the production of Bacillus Thuringiensis-based biopesticide represents up to $40 \%$ of the total production cost. ${ }^{[10]}$ It is therefore essential to find alternative substrates for the production of Btk-based biopesticides at competitive costs. Several authors have indicated that agri-food residues or sludge from sewage treatment plants could be viable alternatives to semi-synthetic substrates. ${ }^{[11-13]}$ In our research group, studies on Btk-based biopesticide production by valorizing starch industrial wastewater were successfully carried out. A process consisting of the following steps was developed: 1) Btk fermentation using starch producing industry wastewater, 2) centrifugation of the fermented broth obtained and 3) the formulation composed of an optimized ratio of suspension of 
centrifuged slurry, fermented broth volume and adjuvants (protective and stabilizing agents). However, the low productivity in terms of formulation volume obtained per unit volume of the fermented broth has led to the research on fortification of the starch industry wastewater with another potential substrate. This fortification would allow a better concentration of total cells, viable spores and delta endotoxin in the fermented broth. Fortification of starch industry wastewater with other rich substrate can reduce the number of centrifugation steps compared to the non-fortified medium and consequently increase the formulation productivity.

Thus, the aim of this study was to produce biopesticide formulation based on starch producing industry wastewater fortified with soybean medium, and optimization of the formulated product using different adjuvants and their concentration.

\section{Materials and methods}

\section{Btk strain}

Bacillus thuringiensis subsp. kurstaki HD1 (Btk) strain was obtained from Cederlane Laboratories INC (4410 Paletta Court, Bullington, ON, Canada, L7L 5R2). The Btk strain was cultivated and sub-cultured on tryptic soy agar (TSA) at $30^{\circ} \mathrm{C}$ for $12 \mathrm{~h}$. The pure bacterial subculture was stored at $4^{\circ} \mathrm{C}$ until used for inoculum preparation. The SIW was collected from ADM-Ogilvie (Candiac, Quebec, Canada) and was used as culture medium for Btk inoculum preparation.

\section{Growth media}

\section{Inoculum}

The culture medium (SIW) used for Btk fermentation was obtained from ADM-Ogilvie (155 Avenue d' Iberia, Candiac, QC J5R 3H1), a cornstarch processing industry. The composition of this

medium, analyzed by ICP-AES axial Vista, is presented in table 1 . The starch residues provide a dissolved organic carbon content of $4990 \mathrm{mg} / \mathrm{L}$ and a dissolved nitrogen content of 460mg/L. SIW $(\mathrm{pH}$ 
3.5) was stored in the cold room at $4^{\circ} \mathrm{C}$ until it was used. Its shelf life was considered to be under two months.

The Btk strain was grown in SIW alone and SIW fortified with soybean (25\% w/v, which means $1 / 4^{\text {th }}$ components of the soybean medium were added to starch industry wastewater) (Table 2). SIW fortified with soybean medium does not contain minerals present in the standard soybean medium. These minerals are found in high concentration in SIW. In addition, glucose was sterilized separately from SIW and the minerals. Glucose was mixed aseptically with the rest of the medium after sterilization. In fact, it is described that a Maillard complex is formed when glucose is sterilized in presence of organic matter (SIW). ${ }^{[9]}$ This complex reduces availability of glucose for microbial growth. The nitrogen concentration of the fortified soybean medium was $14 \mathrm{~g} / \mathrm{L}$. Carbohydrate concentration in SIW and SIW fortified with soybean medium in the beginning $(0 \mathrm{~h})$ and at the end of fermentation (48 hour) is described in table 3.

\section{Fermentation process}

\section{SIW fermentation (2000 L fermenter)}

Btk strain stored at $-80^{\circ} \mathrm{C}$ was spread on agar plates (TSA) and placed in an incubator at $30^{\circ} \mathrm{C}$ for 24 hours. A pure colony of BTK was inoculated in $150 \mathrm{~mL}$ erlenmeyer flask containing $40 \mathrm{~mL}$ of SIW media (pre-sterilized at $121^{\circ} \mathrm{C}$ for 15 minutes) at $\mathrm{pH} 7$, stirred at $200 \mathrm{rpm}$, at $30^{\circ} \mathrm{C}$ for 9 hours. At the end of the first culture stage, the inoculum ( $40 \mathrm{~mL}$ fermented broth) was transferred to a $4 \mathrm{~L}$ erlenmeyer flask containing 2 L SIW medium and incubated under the same operating conditions. After 9 hours of preculture, this served as an inoculum for $150 \mathrm{~L}$ bioreactor with $100 \mathrm{~L}$ SIW content (working volume). The 26 $\mathrm{L}$ of the fermented broth (after $9 \mathrm{~h}$ ) was used to inoculate the $2000 \mathrm{~L}$ bioreactor containing $1300 \mathrm{~L}$ of sterilized SIW. Thus, each volume of the pre-culture corresponded to $2 \%(\mathrm{v} / \mathrm{v})$ of the subsequent culture stage. Before inoculation, $150 \mathrm{~L}$ and $2000 \mathrm{~L}$ bioreactors were sterilized with water before filling it with 100 $\mathrm{L}$ and $1300 \mathrm{~L}$ of SIW medium followed by sterilization at $121^{\circ} \mathrm{C}$ for 20 minutes. After sterilization and the cooling to $30^{\circ} \mathrm{C}$, acid $\left(\mathrm{H}_{2} \mathrm{SO}_{4}\right)$, base $(\mathrm{NaOH})$ and antifoam containers were connected to the fermenter. After that, $2 \mathrm{~L}$ and $26 \mathrm{~L}$ inoculum were ready for transfer into fermenters under sterile conditions. Fermentation was conducted for 48 hours at $\mathrm{pH} 7$ and at $30^{\circ} \mathrm{C}$ temperature. Dissolved oxygen (DO) was 
maintained during the exponential growth phase $(0-12 \mathrm{~h})$ above $30 \%$ by controlling agitation and/or aeration. During the sporulation phase i.e. from $18 \mathrm{~h}$ to $36 \mathrm{~h}$, dissolved oxygen was maintained at $50 \%$ or higher. At the end of fermentation, $\mathrm{pH}$ was adjusted to 4.5 to avoid crystal protein solubilization by active proteases (produced during fermentation) at basic $\mathrm{pH} .{ }^{[10]}$ During fermentation, samples were collected after every 3 hours during the first 12 hours of fermentation and every 6 hours until 48 hours. All samples were analyzed for total cells count, viable spores count, and endotoxin concentration.

\section{Fermentation for SIW fortified with soybean medium (150 L fermenter)}

Inoculum preparation: Starch industry wastewater was supplemented with soybean medium at $25 \%(\mathrm{w} / \mathrm{v})$ for inoculum preparation. The inoculum volume corresponded to $2 \%(\mathrm{v} / \mathrm{v})$ of the bioreactor working volume. $150 \mathrm{~L}$ bioreactor had a working volume of $100 \mathrm{~L}$. Thus, the inoculum consists of two steps: 1) a $150 \mathrm{~mL}$ erlenmeyer flask containing sterilized $40 \mathrm{~mL}$ of SIW and inoculated with a single strain of Btk. Fermentation took place at $\mathrm{pH}$ 7, at $30^{\circ} \mathrm{C}$ temperature, stirring $200 \mathrm{rpm}$ for 9 hours. 2) At the end of this culture, the fermented broth obtained was transferred to a $4 \mathrm{~L}$ Erlenmeyer flask containing $2 \mathrm{~L}$ of SIW medium. Fermentation under the same operating conditions was carried out for 9 hours. This served as inoculum for $150 \mathrm{~L}$ fermenter.

Fermentation: $150 \mathrm{~L}$ bioreactor (100L worling volume) containing SIW fortified with 25\% soybean medium was sterilized and inoculated with inoculum (prepared above). The fermentation was conducted for $48 \mathrm{~h}$ as described above. At the end of fermentation, the $\mathrm{pH}$ of the fermented broth was adjusted to 4.5 to avoid the solubilization of crystal proteins by active proteases. Samples were collected after every 3 hours during the first 12 hours of fermentation and every 6 hours until 48 hours. All samples were analyzed for total cells, viable spores count, and endotoxin concentration. Entomotoxicity was determined for the final sample at the end of the fermentation.

\section{Total cell and viable spore count}


Total cells count and spores count were determined by counting bacterial colony forming units (CFU) on TSA (Tryptic Soy Agar) plates. All the CFU counts were obtained from an average value of measurements conducted in triplicates. For total spore count, serially diluted samples were placed in a water bath (Buchler Instruments) at $80^{\circ} \mathrm{C}$ for $10 \mathrm{~min}$ and immediately immersed in ice for $10 \mathrm{~min}$. Then, $0.1 \mathrm{~mL}$ of diluted sample was plated on TSA medium and incubated at $30^{\circ} \mathrm{C}$ for $24 \mathrm{~h}$ (Imperial II Incubator oven). The presented values are the mean of three separate measurements \pm standard deviation (SD).

\section{Endotoxin concentration}

Btk produces cry toxins encoded by different cry genes found on Btk plasmids. Cry toxins consists of parasporal inclusions, which contains crystal proteins or endotoxins. They have a large spectrum of action against larvae of Lepidoptera, Diptera, and Coleoptera. ${ }^{[11]}$ Endotoxin concentration was determined based on the solubilization of cry proteins under alkaline conditions. ${ }^{[12]}$ One $\mathrm{mL}$ of each sample was centrifuged at $10,000 \mathrm{~g}$ for $10 \mathrm{~min}$ at $4^{\circ} \mathrm{C}$. The pellet containing the mixture of spores, crystal proteins, and cell debris was used to estimate the soluble insecticidal proteins (delta-endotoxin) in alkaline medium. The pellets were washed thrice with $1 \mathrm{~mL}$ of $0.14 \mathrm{M} \mathrm{NaCl}$ and $0.01 \%$ Triton X-100 solutions. This washing step aids in the removal of soluble proteins and proteases, which might be sticking to the centrifuged pellets affecting the integrity of the crystal proteins. ${ }^{[5]}$ The pellets of crystal proteins were dissolved in $0.05 \mathrm{~N} \mathrm{NaOH}\left(\mathrm{pH} \mathrm{12.5)}\right.$ for 3 hours at $30^{\circ} \mathrm{C}$. After crystal solubilization, the suspension was centrifuged at $10000 \mathrm{~g}$ for $10 \mathrm{~min}$ at $4^{\circ} \mathrm{C}$, and the pellet containing the spores and cell debris was discarded. The supernatant containing the insecticidal crystal proteins was used to determine the concentration of delta-endotoxin by the Bradford method using bovine serum albumin (BSA) as a

protein standard. ${ }^{[13]}$ The presented values are the mean of three separate experiments \pm Standard Deviation (SD).

\section{Batch and continuous centrifugation}


Centrifugation is described as the most efficient and least expensive method to recover and concentrate the active ingredients of Btk. ${ }^{[14]}$ It consists of two phases: 1) a pellet or cream depending on their water content and 2) a supernatant. When centrifugation for Btk fermented broth was carried out in batch mode, the concentrate obtained was pellet (low water content), while the continuous centrifugation of Btk fermented broth produced a cream (high water content). The concentration of the active ingredients in the cream/pellet is essential since the treatment in the forest consists of $1.5 \mathrm{~L}$ biopesticide/ha. ${ }^{[15]}$ It is therefore essential that the formulation contains viable spores and protein crystals in high concentration. In this study, continuous centrifugation was performed to concentrate the fermented broth (150 $L$ and 2000 L bioreactors).

SIW supplemented with soybean (150L: 100L working volume) and SIW (2000L: 1300L working volume) fermented broths were undergone through continuous centrifugation (GEA GEA Westfalia separator, model: CSC $150647715000 \mathrm{~g}$ x 11800rpm). Centrifugation of SIW fermented broth resulted in $60 \mathrm{~L} \mathrm{cream}$ (from $1264 \mathrm{~L}$ of centrifuged broth) while centrifugation of SIW fortified with soybean fermented broth resulted in $7 \mathrm{~L}$ cream (from $96 \mathrm{~L}$ of centrifuged broth). The parameters optimized for centrifugation of SIW fortified with soybean fermented broth were:

Discharge time: $2.2 \mathrm{~min}$

Feed speed: $5 \mathrm{~L} / \mathrm{min}$

Centrifugation speed: $15000 \mathrm{~g}$

Back pressure: 8.5 psi

Whereas for SIW fermented broth centrifugation, the optimized parameters were:

Discharge time: $2.5 \mathrm{mn}$

Feed speed: $10 \mathrm{~L} / \mathrm{min}$

Centrifugation speed: $15000 \mathrm{~g}$ 
Back pressure: $8.5 \mathrm{psi}$

Prior to centrifugation, $4 \mathrm{~L}$ and $36 \mathrm{~L}$ volume of fermented broth were removed from 100 and $1300 \mathrm{~L}$ of fermented broth respectively for preparations of formulation, which consisted of fermented broth, cream and various additives (Table 4). The final volume of formulation for the SIW fortified with soybean medium was $96 \mathrm{~L}$ (from $1264 \mathrm{~L}$ of broth centrifuged) while the final volume for SIW was $11 \mathrm{~L}$ (from $96 \mathrm{~L}$ of broth centrifuged).

A diluted formulation from the SIW fortified with soybean (F2d) formulation was also produced. In this process, a $15 \mathrm{~L}$ volume of fermented broth was removed from the SIW fortified with soybean fermented broth (100 L), before centrifugation. The suspension obtained after centrifugation was $6 \mathrm{~L}$ (from $85 \mathrm{~L}$ of broth centrifuged). This volume was mixed with the $15 \mathrm{~L}$ fermented broth and adjuvants (Table 4) for a final volume of $21 \mathrm{~L}$.

\section{Biopesticide formulation}

The formulation refers to the downstream stage of the biopesticide production process that aims to achieve stability, integrity and efficacy over time and space. ${ }^{[6]}$ The formulation based on ratio of cream and fermented broth ensures optimal entomotoxicity and physical properties of the biopesticide. It is supplemented with different additives. The latter must be environment friendly, inert towards the active ingredients (spores, endotoxins, cells) while ensuring their role. Thus, the formulation was composed of 1) phagostimulant such as molasses, 2) suspending agents: sorbitol, potassium silicate, 3) ultraviolet radiation protection agent: molasses, 4) anti-corrosion agent: potassium silicate, 5) antimicrobial agent: propeonic acid, sorbic acid, 6) adhesive agents: xantham gum, carboxymethylcellulose, molasses,7) buffer agent. The concentrations of each agent depend on the characteristics of the substrate, i.e. suspended solids, particle size, viscosity. The formulations of SIW, SIW fortified with soybean and F2d are shown in Table 4.

\section{Particle size}


Particle size analysis was carried out using a Horiba laser scattering particle size analyzer (LA950), to produce a particle size distribution. The stirrer and recirculation pump speed were kept at 250 and $500 \mathrm{rpm}$ to minimize the breakage of flocculated particles. Each sample was analyzed 3 times to confirm the validity and reproducibility of the results. This method was based on the principles of Fraunhoffer diffraction and Mie scattering. Results obtained are described below:

D50 indicates that $50 \%$ of the particle sizes fall between the measured value.

D90 indicates that $90 \%$ of particles are smaller than the obtained value.

D10 indicates that $10 \%$ of the particles have a smaller size than the obtained value.

\section{Viscosity}

An optimal viscosity will provide uniform distribution of active ingredients on the tree leaves and promote efficient applications. Viscosity was measured using the Brookefield DVII pro, which is a viscometer with Rheocalc 32, SC-34 pin software (small sample adapter). ${ }^{[16]}$ The presented values are the mean of three separate experiments \pm Standard Deviation (SD).

\section{U.V radiation}

Ultraviolet radiation tests are determined based on a specific ultraviolet emission source (Transilluminator, UVP®, San Gabriel, CA, USA) with maximum emission spectra of $366 \mathrm{~nm}(\mathrm{UV}-\mathrm{A})$ and $312 \mathrm{~nm}$ (UV-B). These radiation spectra are considered lethal to spores and inactive crystal proteins. Several studies have mentioned the lethal nature of UV-B radiation, which affected the genetic material of viable spores. Several authors mentioned the implication of UV radiation in the inactivation of crystal

proteins. ${ }^{[17]}$ Crystal proteins would adsorb on chromophores (presently uncharacterized) from the fermented broth. These chromophores absorb light at 300-380nm, and pass their excited state to oxygen molecules that convert into free and highly reactive radicals. These radicals are said to attack the 
tryptophan chains present in endotoxins crystals, affecting the integrity of these proteins and causing their inactivation. Hadapad proposed the use of reductive agents (Molasses) in Btk formulations to protect crystal proteins from oxygen radicals. ${ }^{[18]}$

The experiment was carried out as follows: a cubical box covered with mirror (to reflect the U. V. rays on the six surfaces) contained the vials (containing $1 \mathrm{ml}$ of formulations), which were placed on an aluminum-coated spreader from $20 \mathrm{~cm}$ of the U. V. lamp. Samples of fermented broth (SIW and SIW fortified with soybean) and formulations (SIW, SIW fortified with soybean, F2d, Foray 76B and Btk sander's) were removed at each $0,5,10,20,30,45,90$ and $300 \mathrm{~h}$. These samples determined the exposure time to decrease the entomotoxicity by half $\left(\mathrm{Tx}_{0.5}\right)$ for the different samples studied. ${ }^{[9]}$ The presented values are the mean of three separate experiments \pm Standard Deviation (SD).

\section{Rainfastness}

The rainfastness test was carried out in the forest application conditions where $1.5 \mathrm{~L}$ of formulation was applied per hectare of the forest. The treated area was equivalent to $0.15 \mathrm{~mL}$ per square meter $\left(\mathrm{m}^{2}\right)$. The floor area of a young balsam fir was about one $\mathrm{m}^{2}$ (Fig 1$)$. Thus, $0.15 \mathrm{~mL}$ of our formulations (SIW, SIW fortified with soybean and F2d) was enough to treat a young balsam fir tree. The control formulation consisted of adjuvants without the active Btk agent (broth or cream). The different formulations were applied to the balsam fir trees and then after 5 days of the application, a watering corresponding to $3 \mathrm{~cm}$ of rainfall on the ground was applied, which represented $300 \mathrm{ml}$ or a heavy rainfall of $30 \mathrm{~mm}$.

The evaluation of adhesiveness was done by impregnating the needles of balsam fir trees on a TSA agar at different time periods ( $t=0,1,24,48,72 \mathrm{~h}, 5$ days, 6 days, 7 days) (Fig 2). The number of total residual cells was determined to evaluate the adhesiveness of the formulation.

\section{Suspending Agent}

Btk liquid formulations are often stored before use in warehouses or during aerial application. It is important that particles of formulation remain uniformly distributed in solution during storage. The 
application of good biopesticide requires that the formulated product exhibit a proper suspension and dispersion property. Number of spores and protein crystals concentration per droplet are important parameters during dispersion. In fact, when the larvae ingest a non-lethal dose droplet, they may stop eating for several days but will survive again and continue to cause damage. ${ }^{[19]}$

Sorbitol is often used in the food industry and in a variety of biopesticides to impart dispersing and suspending properties to formulations. ${ }^{[20,21]}$ Based on the substrate and suspended solids concentration, sorbitol optimization is studied. The experimental design of this study is carried out by taking $50 \mathrm{~mL}$ of the formulation and suspending it in $100 \mathrm{~mL}$ of distilled water. This mixture is subjected to a 30-minute settling period and turbidity of the supernatant, total solids and settling materials are measured. The percentage of suspension of: SIW formulation (F.SIW), SIW formulation sorbitol-free (C. SIW), formulation of SIW fortified with soybean (F. SIW+soybean), formulation of SIW fortified with soybean sorbitol-free (C. SIW+soybean), Foray 76B and F2d is determined as follows:

$\frac{\text { Turbidity }(N T U)}{\text { Total solids }\left(\frac{g}{L}\right)-\text { Settling solids }\left(\frac{g}{L}\right)}$

NTU : Nephelometric Turbidity Unit

\section{Zeta potential}

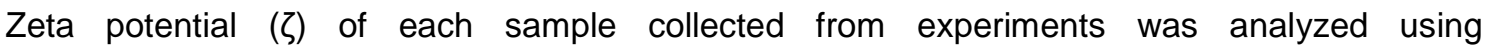
Zetaphoremeter IV, Zetacompact Z8000 (CAD instrumentation France). The zeta potential values were obtained from the average of 3 measurements. The average values are presented with its half-width confidence interval at 95\% confidence level.

\section{Entomotixicity}


The entomotoxicity $(\mathrm{Tx})$ of the samples was estimated by bioassay against third instar larvae of spruce budworm following the diet incorporation method. The detailed procedure has been presented in literature $[10,14,22]$. The entomotoxicity is the mean of values obtained from three independent experiments \pm SD.

\section{Results}

\section{Btk fermentation using SIW or SIW fortified with soybean medium}

Btk cell growth results presented in Fig $3(\mathrm{~A})$ exhibited exponential growth during $0 \mathrm{~h}$ to $12 \mathrm{~h}$ of fermentation for both substrates. SIW fortified with soybean $25 \%(\mathrm{w} / \mathrm{v})$ had a cell count of $1.41 \times 10^{7}$ $\mathrm{CFU} / \mathrm{mL}$ at $0 \mathrm{~h}$ while the SIW showed a cell count of $1.5 \times 10^{6} \mathrm{CFU} / \mathrm{mL}$ at $0 \mathrm{~h}$. Moreover, at $30 \mathrm{~h}$ of fermentation, the maximum total cell count was $1.65 \times 10^{9} \mathrm{CFU} / \mathrm{mL}$ for SIW fortified with soya, while for the SIW medium, the maximum total cell count at 12 hours of fermentation was $2 \times 10^{8} \mathrm{CFU} / \mathrm{mL}$.

The sporulation (Fig 3B) follows the same trend in SIW and SIW fortified with soybean, it appears that the presence of increased nitrogen source in the fortified medium did not inhibit sporulation as described by Zouari et al. ${ }^{[12]}$

\section{Formulation}

\section{Fermented broth/cream optimization}

When formulated, the cream obtained from centrifugation was concentrated in terms of total cell count (SIW: $3.16 \times 10^{9} \mathrm{CFU} / \mathrm{mL}$; SIW fortified with soybean medium: $9.6 \times 10^{9} \mathrm{CFU} / \mathrm{mL}$ ), viable spores count (SIW: $2.98 \times 10^{9} \mathrm{CFU} / \mathrm{mL}$; SIW fortified with soybean medium: $8.95 \times 10^{9} \mathrm{CFU} / \mathrm{mL}$ ) and endotoxins (SIW: $4224 \mu \mathrm{g} / \mathrm{mL}$; SIW fortified soybean: $9570 \mu \mathrm{g} / \mathrm{mL}$ ). The concentration of Btk active ingredient in centrifuged creams of SIW fortified with soybean and SIW alone fermented broth resulted in larvicidal potency exceeding $30 \mathrm{BIU} / \mathrm{ha}$ (30 BIU/ha for $1.5 \mathrm{~L}$ ). ${ }^{[5,14]}$ In addition, the viscosity of SIW cream and SIW fortified with soybean cream (obtained from centrifuging respective fermented broths) was187 mPas and 198 $\mathrm{mPas}$ respectively. These viscosity values are above the optimum values for application (130-150 mPas). 


\section{Entomotoxicity}

Entomotoxicity determined for the different media presented in Table 5 is in the following order: SIW fortified with soybean $>$ SIW fortified with soybean diluted $(F 2 d)>$ SIW $>$ Foray 76B $>$ SIW fortified with soybean (fermented broth)> SIW fermented broth> Btk sander's. SIW fortified with soybean medium entomotoxicity was almost twice higher than Foray 76B and SIW control. Meanwhile, the formulation from the fermented broth showed lower potential than the formulation from centrifugation.

\section{U.V half life}

The half-life of entomotoxicity ( $\left.\mathrm{Tx}_{0.5}\right)$ was determined for SIW creams, SIW fermented broth, SIW fortified with soybean fermented broth, SIW fortified soybean cream as well as for the formulations of SIW, SIW fortified with soybean, F2d, Foray 76B and Btk sander's (Table 6). The observed results showed that when the fermented broth was not centrifuged or formulated, the half-life of the fermented broth was lower than that obtained in soybean fortified SIW cream and SIW cream. When formulations (SIW, SIW fortified soybean, F2d) mixed with UV protective agents (mixture) were exposed to ultraviolet rays, the half-life obtained was much higher than those of commercial formulations.

\section{Suspending agent}

Suspension results showed high suspensions between 95 and $98 \%$ for formulated SIW, formulated SIW+soybean, F2d, Foray 76B formulations (Fig 4). While the C. SIW (SIW formulation control) and the C. SIW+soybean (SIW+soybean formulation control) without addition of sorbitol had suspensions of $77 \%$ and $79 \%(w / v)$ respectively.

\section{Rainfatness}

Table 6 shows Btk total cell counts of different formulations from fermented broths of SIW alone, SIW fortified with soybean, F2d and control formulations after spraying on balsam fir branches. The control formulation has no Btk suspension. After one hour of suspension, three different Btk formulations showed total cell counts in excess of $300 \mathrm{CFU} / \mathrm{mL}$ on a balsam fir branch, impregnated on a nutrient agar. From 
$24 \mathrm{~h}$ to $48 \mathrm{~h}$ of culture, without watering, the count of total cells remains important. While on Day 5 , an artificial rain of $300 \mathrm{~mL}$ was simulated, the total cell count decreased from $220 \mathrm{CFU} / \mathrm{mL}$ to $180 \mathrm{CFU} / \mathrm{mL}$ for the F2d formulation, $180 \mathrm{CFU} / \mathrm{mL}$ for the SIW formulation and $230 \mathrm{CFU} / \mathrm{mL}$ for the SIW fortified with soybean formulation. The trees were no longer watered for up to a week of cell count. Thus, total cell counts analysis was $125 \mathrm{CFU} / \mathrm{mL}$ for the $\mathrm{F} 2 \mathrm{~d}$ formulation, $100 \mathrm{CFU} / \mathrm{mL}$ for the SIW formulation, 150 CFU/mL for SIW fortified soybean at 7 days.

\section{Discussion}

Bacillus thuringiensis var kurstaki fermentation using SIW or SIW soybean medium showed a lack of lag phase which is due to two factors:

1. Inoculum age, which has been optimized in previous work. ${ }^{[6]}$ For a Btk pre-culture, an inoculum age between 8 and $9 \mathrm{~h}$ is desirable in order to obtain bacterial cells that are free of viable spores. In fact, at a culture age of $12 \mathrm{~h}$ or older, viable spores begin to appear as vegetative cells. Viable spores need nutrients to germinate again before they start new cell divisions. These intermediate steps in cell proliferation and protein crystal synthesis leads to lag phase and reduce biomass to substrate yield.

2. The second factor is the pre-culture medium, which must be of the same nature as the bioreactor containing the final fermentation medium (SIW or SIW fortified with soybean medium). This bacterial adaptation leads to arsenal enzyme synthesis in pre-culture such as extracellular proteases, amylases and other enzymes necessary for nutrient degradation, which are also needed in bioreactor growth. ${ }^{[5,23]}$

It should be noted that fermentation does not end at the maximum cellular concentration as the maturation of viable spores and synthesis of crystal proteins occurs up to 48 hours of fermentation. This maturation ends with viable spores and release of crystal proteins from the cell. ${ }^{[6]}$

Furthermore, 1 log difference in total cells count between the two media can be explained by the fortification of SIW medium with soybean. In fact, LC-MS-MS results showed (Table 3), a high carbon 
concentration (in form of reduction sugar) available for Btk in the fortified medium. Also, these results indicate the bacterial preference for glucose and fructose as after 48 hours of fermentation, their concentration substantially decreased. While Xylose, which is a 5-carbon carbohydrate, cannot be metabolized by Btk. ${ }^{[24]}$ Total nitrogen deficiency in SIW medium $(0.45 \mathrm{~g} / \mathrm{L})$ is amended by SIW fortification with soybean $(14 \mathrm{~g} / \mathrm{L})$.

From a biochemical point of view, the scarcity of nutrients such as ammonia, phosphate can trigger sporulation and protein synthesis. ${ }^{[25]}$ However, the fortified medium has sufficient sucrose, glucose and fructose, which would ensure fulfillment of energy demand during the sporulation and synthesis of the crystal proteins. High availability of ATP would positively affect the synthesis of spore and protein crystals. [26, 27] The sporulation and synthesis of crystal proteins are phenomena that mobilize energy. Authors Mazmira et al. ${ }^{[23]}$ showed that the presence of $8 \mathrm{~g} / \mathrm{L}$ of reducing sugars (glucose, fructose etc.) would trigger the synthesis of delta endotoxin at an advanced cell growth stage (Fig 3C). However, a very high concentration of glucose (or other reducing sugar) would stop the synthesis of enzymes needed to metabolize complex carbon. ${ }^{[28]}$

In addition, endotoxins are composed of $95 \%$ protein and $5 \%$ carbohydrates. The presence of amino acids from the soybean medium, used to fortify SIW, such as glutamic acid and aspartic acid are essential for endotoxin synthesis and sporulation. ${ }^{[29,30]}$ Some work has shown that gram-positive bacteria such as Btk were able to accumulate certain amino acids, which could be used later as an energy or protein source for sporulation and synthesis of crystal proteins. ${ }^{[31,32]}$ Significant results in SIW fortified with soybean require further dilution, which resulted in a diluted formulation (F2d). This strategy produces high volume of diluted formulation and with entomotoxicity equivalent to non-fortified SIW medium and Foray $76 \mathrm{~B}$ (please refer to the entomotoxicity section).

While the $30 \mathrm{BIU} / \mathrm{ha}$ potential has been described as sufficient to treat 1 ha of forest area at a volume of $1.5 \mathrm{~L}$ with Foray $76 \mathrm{~B}$ biopesticide. ${ }^{[20]}$ These authors reported that when the same volume of biopesticide $(1.5 \mathrm{~L})$ and the same forest area to be treated (1 ha) were used with a 50 BIU Foray $76 \mathrm{~B}$ biopesticide, larval mortality results were similar to those obtained with $30 \mathrm{BIU} / \mathrm{ha}$. Creams from SIW and 
SIW fortified with soybean were diluted with their respective fermented broth in different proportions. These dilutions were studied in terms of a cream-to-fermented broth ratio so that the total cells count, viable spores count, crystal proteins, entomotoxicity and viscosity in the different formulations (SIW, soybean fortified SIW and F2d) to be equivalent to commercial biopesticides (Table 4 and Table 5). This dilution also has the advantage of increasing the formulation volume produced, reducing the viscosity of the cream in the required range and also increasing the particle size. During centrifugation, the particles of the cream undergo shocks that reduce their size (SIW: $1.07 \mu \mathrm{m}$, soybean fortified SIW $1.40 \mu \mathrm{m}$ ). Thus, a direct addition of fermented broth to the cream provides an overall average D50 particle size relatively comparable to Foray 76B (Table 4).

During transport or storage, Btk formulations may be subjected to contamination by microorganisms. Crystal proteins can also be solubilized and become inactive during these periods in alkaline media through proteolytic solubilization. Also, during application, volatile compounds such as aldehydes, ketones, carboxylic acids, etc. present on leaves may affect the formulation $\mathrm{pH}$ and inhibit the Bt active components. ${ }^{[3,34]}$ In fact, at low and high $\mathrm{pH}$, Btk active ingredients become inactive. ${ }^{[35,36]}$ Ascorbic acid, propenoic acid and acetic acid at low concentrations have permitted (Table 4) to control the microbial contamination. ${ }^{[14,6]}$ Acetic acid and sodium acetate form a buffer solution that stabilizes the $\mathrm{pH}$ of the formulations at 5 . This buffer solution is bacteriostatic for many bacteria and stabilizes the $\mathrm{pH}$ of the formulation during application to foliage and during storage or transport.

Viscosity is a very important property and must be taken into account during application. It is among the parameters that influence the droplet size and their deposition on the treated surface. It has been described that low viscosity formulations below $100 \mathrm{mPas}$ tend to produce small droplets and low deposition on treated surfaces when compared to low-volatility formulations with higher viscosity (130150mPas). ${ }^{[37,38]}$ When the droplets are small, two possibilities are considered:

3. The quantity of the biopesticide in the droplet consequently decreases the active ingredient concentration. There is a cubic relationship between the droplet diameter and its volume. 
Reducing the diameter of droplets in a spray cloud by half will reduce the volume of each droplet by a factor of $8 .{ }^{[39]}$

4. The behaviour of the droplet, i.e. the place where it is carried away and the place where it is deposited. Small droplets may cause more drift or deposition out of the treated area. During the watercourses and agricultural activities in the area to be treated, controlling drift by optimizing viscosity is important.

Thus, in various formulations, thickening agents such as xantham gum, carboxymethylcellulose (CMC), molasses and potassium silicate were studied. These agents are considered safe for human health, animals, the environment and biopesticide active ingredients. ${ }^{[14]}$ The different thickeners mentioned above have been proportioned according to the ratio of fermented broth/cream and the nature of the substrates (SIW and soybean fortified SIW) in order to obtain intervals of optimum viscosity (Table 4) comparable to Foray $76 \mathrm{~B} .{ }^{[40]}$

Btk entomotoxicity is an essential measure to determine the effectiveness of a Btk formulation. Entomotoxicity depends on several factors:

5. Larvae: Btk is effective against larvae of lepidoptera and certain diptera and beetles. The 3rd and 6th stage larvae are actively feeding larvae. For the application of the product to be effective, larvae should therefore be healthy and in the right period of maturation to feed.

6. Organoleptic properties of the biopesticide: To encourage larvae to feed (phagostimulance), Btk-based biopesticides are often supplemented with nutrients such as sugar (energy), soya or molasses (taste and odour). ${ }^{[41]}$

7. The nature of crystal proteins: Crystal proteins contains endotoxins. Depending on the nature of the substrate, a) complex: sludge, starch wastewater or b) simple: semi-synthetic medium, the virulent nature and endotoxins concentration in crystal proteins differ. ${ }^{[42]}$

8. Concentration of viable spores: The larvicidal action of Btk is based on action of crystal proteins attached to the receptors of the middle intestine of larvae. This action is in concomitance with the germination of the spores, which subsequently leads to septicemia in the larvae. Valero 
${ }^{[43]}$ indicates that a biopesticide containing both crystal proteins and spores is 4 times more effective than a biopesticide containing either.

9. Other virulence factors: Btk synthesizes other virulence factors that are poorly studied, such as proteases, insecticidal vegetative proteins (acting as crystals protein on other receptors), chitinases and other zwittermicin. These soluble compounds mixed with cream at different ratios have shown a positive effect on Btk's larvicidal properties. ${ }^{[45,5]}$

Results from the SIW fortified with soybean formulation demonstrate that high concentration of Btk active ingredient found in this formulation is a major factor in the higher entomotoxicity of biopesticide. While F2d formulation has total cells count, viable spores count and endotoxin concentrations slightly below that of SIW formulation. Entomotoxicity determined for F2d was higher than SIW. These results may be explained by the presence of more larvicidal crystals in F2d formulation. Also, the presence of soybean and sugar in this medium could lead to phagostimulation of larvae when compared to the SIW medium. ${ }^{[15]}$ It should also be noted that entomotoxicity of SIW formulation is superior to Foray's despite of higher concentration of total cells count, viable spores count and endotoxin in Foray 76B. These results reflect the data obtained by Barnabé et al. ${ }^{[42]}$ who reported that entomotoxicity using municipal secondary sludge as substrate was superior to Foray 76B. The complex components present in non-conventional substrates such as sludge or wastewater resulted in virulent, lethal protein crystals containing high concentrations of endotoxin when compared to formulations prepared from the fermented broths of easily biodegradable substrates. Fermented broths have inferior entomotoxicity to formulations. In fact formulations has higher concentration of active ingredients (by centrifugation) and possesses phagostimulant that stimulate larvae's appetite.

Creams contain more active ingredients than fermented broths and concentration of fermented broth provides an important larvicidal potential in creams. Further, after centrifugation, the concentration of suspended solids (SIW and soybean particles) increased in the cream, which provided a protective barrier against ultraviolet rays. ${ }^{[24]}$ Brar et al. ${ }^{[14]}$ mentioned the presence of chromophore such as hymathomelanic acid in formulations of unconventional (sludge, wastewater) media. This molecule would 
participate in the protection of Btk's active ingredients against UV radiation. While molasses present in the formulations forms a protective layer against the harmful effects of U.V. radiation. Studies showed that molasses has antioxidant activity. It would protect viable spores, DNA and oxidation of crystal proteins. ${ }^{[17,}$ ${ }^{18]}$ The half-life of SIW fortified with soybean formulation was higher than SIW and F2d. Formulation of SIW fortified with soybean is concentrated in Btk's active ingredient. It also has chromophores and high suspended solids concentrations that offer superior larvicide properties and UV protection to the formulated product. When this medium was diluted (F2d), the suspended solids, cell concentrations, viable spores and crystals proteins obtained were equivalent to SIW formulation as well as the resulting $\mathrm{Tx}_{0.5}$. This indicates that there is a correlation between suspended solids, Btk's active ingredients and the protective effect against ultraviolet radiation.

Sorbitol is described as a stabilizer and sequestering agent. Its structure contains hydroxyl radicals $\left(\mathrm{OH}^{-}\right)$which leads to bonding with cations at an acidic pH (formation of $\mathrm{H}_{3} \mathrm{O}^{+}$: studied formulations have $\mathrm{pH}$ 5). These bonds decrease the availability of positive charged ions, molecules and polymers, while negative charges become predominant. At the concentration of sorbitol studied, the sorbitol-complex particles and the excess free sorbitol in the solution repel each other, creating a state of suspension or dispersion in the solution. ${ }^{[19]}$ Table 4 shows the zeta potential value of the different formulations. These values reflect the balance between the repulsive and attractive forces between particles in solution. ${ }^{[6]}$

Moreover, the addition of sorbitol provides stabilization by binding to proteins and provides cryoprotection for formulation (all studied formulations have high protein content). According to authors ${ }^{[14,24]}$ this cryoprotection promotes formulation stability at low temperatures.

With the rainfatness experiment, it was possible to measure for the first time the adhesiveness of the different formulations developed on balsam fir trees, attacked by spruce budworms.

These results demonstrated the persistence of the formulations and their resistance to ultraviolet rays, precipitation and volatile substances (antibiotic properties) that are constantly emitted by conifers to protect against invasive organisms (bacteria, fungi and other). ${ }^{[43,44]}$ Among these volatile substances of 
conifers, acetylene, pinene, bornyl acetate, phellandrene and thujone are listed as antibacterial agents. [45, 46] The buffering power of the formulation conferred by sodium acetate and acetic acid enabled it to resist volatile substances and their effect on $\mathrm{pH}$. While the presence of molasses, xantham gum as thickening agent ensured adhesion of the formulation to the branches despite rainfall. The adhesive property of molasses resulted from the sugar content, which formed cohesive bonds when molasses dried up on the surface. Also, the polymeric chains of amino acids in molasses tend to form a contiguous three-dimensional network in solution. This network is likely to trap water within its structure and resists precipitation washout. ${ }^{[47]}$ Yezza et al. ${ }^{[10]}$ have also shown that starch-based formulations can increase biopesticide persistence and Bt entomotoxicity as starch particles enhanced adhesive properties of the formulation.

This study made it possible to produce a biopesticide formulations with high entomotoxicity by fortifying starch industry wastewater with a soybean medium of $25 \%$ strength. This entomotoxicity is attributed to the presence of high concentration of carbohydrate and nitrogen source, which increased Btk cell growth, sporulation and crystal protein synthesis. The high potential of this formulation needs further dilution and results in a diluted formulation with an entomotoxicity equivalent to the commercial product (Foray 76B formulation). The suspended solids, the nature of the substrate and Btk active ingredient present in industrial starch wastewater provided an important half-life against UV in SIW-based formulations. While the presence of suspending agents such as sorbitol has proven to be effective in dispersion of formulation particles. In addition, adjuvants like molasses, xantham ghum and carboxymethylcellulose have been used to achieve an optimal viscosity for biopesticide application.

\section{Funding and Ethical statement}

The authors are thankful to the Natural Sciences and Engineering Research Council of Canada for financial support (Grants A4984, STR 202047, SCF 192190-96 and Canada Research Chair). The views and opinions expressed in this article are those of authors. This article does not contain any studies with 
human participants or animals performed by any of the authors. AN declares that he has no conflict of *interest. RDT declares that he has no conflict of interest. JV declares that he has no conflict of interest.

\section{Reference}

[1] Blais, J.R. Trends in the frequency, extent, and severity of spruce budworm outbreaks in eastern. Can. J. For. Res. 1983, 13: 539Đ617

[2] Dymond, C.C.; Neilson, E.T.; Stinson, G.; Porter, K.; MacLean, D.A.; Gray, D.R.; Kurz, W.A.; Future spruce budworm outbreak may create a carbon source in eastern Canadian forests. Ecosystems. 2010, 13(6) 917-931

[3] Carrow, J.R. Bacillus Thuringiensis and the spruce budworm. New Brunswick Department of Natural Resources. 1983, Fredericton, New-Brunswick, Canada.

[4] Van Frankenhuyzen, K., Lucarotti, C.; Lavallée, R. Canadian contributions to forest insect pathology and to the use of pathogens in forest pest management. Can. Entomol. 2016, 148(S1) S210-S238.

[5] Vu, D.; Tyagi, R.D.; Brar, S.K.; Valéro, J.R.; Surampalli, R.Y. Starch industry wastewater for production of biopesticides-Ramifications of solids concentrations. Environ. Technol. 2009, 30: 393-405.

[6] Ndao, A.; Sellamuthu, B.; Gnepe, J.R.; Tyagi, R.D.; Valero, J.R. Pilot-scale biopesticide production by Bacillus thuringiensis subsp. kurstaki using starch industry wastewater as raw material. J. Environ. Sci. Heal. B. 2017, 52(9) 623-630.

[7] De Maagd, R.A.; Bravo, A.; Crickmore, N. How Bacillus thuringiensis has evolved specific toxins to colonize the insect world. Trends. Genet. 2001, 17(4) 193-199.

[8] Bravo, A.; Gill, S.S.; Soberon, M. Mode of action of Bacillus thuringiensis Cry and Cyt toxins and their potential for insect control. Toxicon. 2001, 49(4) 423-435.

[9] Zhang, X.; Yan, S.; Tyagi, R.D.; Surampalli, R.; Valéro, J.R. Wastewater sludge as raw material for microbial oils production. Appl. Energ. 2014, 135 192-201.

[10] Yezza, A.; Tyagi, R.D.; Valero, J.R.; Surampalli, R.Y. Bioconversion of industrial wastewater and wastewater sludge into Bacillus thuringiensis based biopesticides in pilot fermentor. Bioresour. Technol. 2006, 97(15) 1850-1857.

[11] Schnepf, E.; Crickmore, N.V.; Van Rie, J.; Lereclus, D.; Baum, J.; Feitelson, J.; Dean, D.H. Bacillus thuringiensis and its pesticidal crystal proteins. Microbiol. Mol. Biol. Rev. 1998, 62(3) 775-806.

[12] Zouari, N.; Jaoua, S. The effect of complex carbon and nitrogen, salt, Tween-80 and acetate on delta-endotoxin production by a Bacillus thuringiensis subsp kurstaki. J. Ind. Microbiol. Biotechnol.1999, 23.6: 497-502.

[13] Bradford, M.M. A rapid and sensitive method for the quantitation of microgram quantities of protein utilizing the principle of protein-dye binding. A. biochem.1976, 72(1-2), 248-254. 
[14] Brar, S.K.; Verma, M.; Tyagi, R.D.; Valéro, J.R.; Surampalli, R.Y. Screening of different adjuvants for wastewater/wastewater sludge-based Bacillus thuringiensis formulations. J. Econ. Entomol. 2006, 99(4) 1065-1079.

[15] Bauce, É.; Carisey, N.; Dupont, A.; Van Frankenhuyzen, K. Bacillus thuringiensis subsp. kurstaki aerial spray prescriptions for balsam fir stand protection against spruce budworm (Lepidoptera: Tortricidae). J. Econ. Entomol. 2004, 97(5) 1624-1634.

[16] Gnepe, J.R.; Tyagi, R.D.; Brar, S.K.; Valéro, J.R.; Surampalli, R.Y. Corrosion and stability study of Bacillus thuringiensis var. kurstaki starch industry wastewater-derived biopesticide formulation. J. Environ. Sci. Heal. B. 2014, 49(11) 889-896.

[17] Guimaraes, C.M.; Glao, M.S.; Martinez, S.S.; Pintado, A.I.; Pintado, M.E.; Bento, L.S.; Malcata, F.X. Antioxidant activity of sugar molasses, including protective effect against DNA oxidative damage. J. food. Sci. 2007, 72(1).

[18] Hadapad, A.B.; Hire, R.S.; Vijayalakshmi, N.; Dongre, T.K. UV protectants for the biopesticide based on Bacillus sphaericus Neide and their role in protecting the binary toxins from UV radiation. J. Invertebr. Pathol. 2009,100(3) 147-152.

[19] Smirnoff, W.A.; Valéro, J.R. Characteristics of a highly concentrated Bacillus thuringiensis formulation against spruce budworm, Choristoneura fumiferana (Lepidoptera:Tortricidae). Can. Ent. 1983, 115:443444.

[20] Pazhang, M.; Mehrnejad, F.; Pazhang, Y.; Falahati, H.; Chaparzadeh, N. Effect of sorbitol and glycerol on the stability of trypsin and difference between their stabilization effects in the various solvents. Biotechnol. Appl. Biochem. 2016, 63(2) 206-213.

[21] Smirnoff, W.A.; Juneau, A. Physical analysis of the dispersion of Bacillus thuringiensis [bacterial insecticide] against spruce budworm." Information Report Canadian Forestry Service (Canada).1982, no. LAJ-X-55.

[22] Dulmage, H.T.; Boening, O.P.; Rehnborg, C.S.; Hansen, G.D. A proposed standardized bioassay for formulations of Bacillus thuringiensis based on the international unit. J. Invertebr. Pathol. 1971, 18(2) 240245.

[23] Mazmira, M.M.; Ramlah, S.A.A.; Rosfarizan, M.; Ling, T.C.; Arliff, A.B. Effect of saccharides on growth, sporulation rate and $\delta$-endotoxin synthesis of Bacillus thuringiensis. Afr. J. Biotechnol. 2012, 11(40) 9654-9663.

[24] Brar, S.K.; Verma, M.; Tyagi, R.D.; Valéro, J.R.; Surampalli, R.Y. Efficient centrifugal recovery of Bacillus thuringiensis biopesticides from fermented wastewater and wastewater sludge. Water. Res. 2006, 40(6) 1310-1320.

[25] Liu, C.M.; Tzeng, Y.M. Characterization study of the sporulation kinetics of Bacillus thuringiensis. Biotechnol. Bioeng. 2000, 68(1)11-17.

[26] Rowe, G.E.; Margaritis, A. Bioprocess design and economic analysis for the commercial production of environmentally friendly bioinsecticides from Bacillus thuringiensis HD-1 kurstaki. Biotechnol. Bioeng. 2004, 86(4) 377-388.

[27] Ben Khedher, S.; Jaoua, S.; Zouari, N. Overcome of carbon catabolite repression of bioinsecticides production by sporeless Bacillus thuringiensis through adequate fermentation technology. Biotechnol. Res. 2014, Int 2014. 
[28] Ghribi, D.; Abdelkefi-Mesrati, L.; Mnif, I.; Kammoun, R.; Ayadi, I.; Saadaoui, I.; Chaabouni-Ellouze, S. Investigation of antimicrobial activity and statistical optimization of Bacillus subtilis SPB1 biosurfactant production in solid-state fermentation. Biomed. Res. Int. 2012, 2012.

[29] Dharmsthiti, S.C.; Pantuwatana, S.; Bhumiratana, A. Production of Bacillus thuringiensis subsp. israelensis and Bacillus sphaericus strain 1593 on media using a byproduct from a monosodium glutamate factory. J. Invertebr. Pathol.1985, 46(3) 231-238.

[30] Kanjanamaneesathian, Mana. Bacillus for Rice Cultivation in Thailand. Beneficial Microorganisms in Agriculture, Aquaculture and Other Areas. Springer. Cham. 2015, 81-100

[31] Gale, E.F.; Shirley Taylor, E. The Assimilation of Amino-acids by Bacteria: 2. The Action of Tyrocidin and some Detergent Substances in Releasing Amino-acids from the Internal Environment of Streptococcus faecalis. Microbiol.1947, 1.1: 77-84.

[32] Conde, A.; Diallinas, G.; Chaumont, F.; Chaves, M.; Gerós, H. Transporters, channels, or simple diffusion Dogmas, atypical roles and complexity in transport systems. Int. J. Biochem. Cell. Biol. 2010, 42(6) 857-868.

[33] Smirnoff, W.A. Effects of volatile substances released by foliage of Abies balsamea. J. Invertebr. Pathol.1972, 19(1): 32-35.

[34] Ferry, N.; Edwards, M.G.; Gatehouse, J.A.; Gatehouse, A.M.R. Plant-insect interactions: molecular approaches to insect resistance. Curr. Opin. Biotechnol. 2004,15: 155-161.

[35] Salama, H.S.; and O. N. Morris. "The use of Bacillus thuringiensis in Developing Countries en" Bacillus thuringiensis An Environmental Biopesticide: Theory and Practice". Entwistle PF et. al." (1993): 237-253.

[36] Aranda, E.; Lorence, A.; Trejo del Refugio, M. Rural production of Bacillus thuringiensis by solid. Entomopathogenic Bacteria: from Laboratory to Field Application. 2013, 317.

[37] Hilz E.; Arnoldus, V.W.P. Spray drift review: the extent to which a formulation can contribute to spray drift reduction. Crop. Prot. 2013, 44 (2013): 75-83

[38] Harrison, G.M.; Mun,R.; Cooper, G.; Boger, D.V. A note on the effect of polymer rigidity and concentration on spray atomisation. J. Nonnewton. Fluid. Mech.1999, 85(1) 93-104.

[39] Dobson, H.; William, K. Pesticide Application: Mastering And Monitoring. Ecological Monitoring Methods for the Assessment of Pesticide Impact in the Tropics. Chatham, UK: Natural Resources Institute. 2002, 1-20.

[40] Adjallé, K.D.; Vu, K.D.; Tyagi, R.D.; Brar, S.K.; Valéro, J.R.; Surampalli, R.Y. Optimization of spray drying process for Bacillus thuringiensis fermented wastewater and wastewater sludge. Bioproc. Biosyst. Eng. 2011, 34(2) 237-246.

[41] Broderick, N.A.; Goodman, R.M.; Raffa, K.F.; Hande1sman, J. Synergy Between Zwittermicin A and Bacillus thuringiensis subsp. kurstaki Against Gypsy Moth (Lepidoptera: Lymantriidae). Environ. Entomol. 2000, 29(1): 101-107.

[42] Barnabé, S.; Brar, S.K.; Tyagi, R.D.; Beauchesne, I.; Surampalli, R.Y. Pre-treatment and bioconversion of wastewater sludge to value-added products-Fate of endocrine disrupting compounds. Sci. Total. Environ. 2009, 407(5) 1471-1488. 
[43] Valero, J.R. Microbiologie contre tordeuse, recherches à Forêt-Canada, région du Québec. L'Aubelle.1990, 12-15

[44] Guenther, A.; Hewitt, C.N.; Erickson, D.; Fall, R.; Geron, C.; Graedel,T.; Pierce, T. A global model of natural volatile organic compound emissions. J. Geophys. Res. Atmos.1995, 100 (D5) 8873-8892.

[45] Ehn, M.; Thornton, J.A.; Kleist, E.; Sipilä, M.; Junninen, H.; Pullinen, I.; Lopez-Hilfiker, F. A large source of low-volatility secondary organic aerosol. Nature. 2014, 506 (7489) 476.

[46] Isidorov, V.A.; Zenkevich, I.G.; Ioffe, B.V. Volatile organic compounds in the atmosphere of forests. Atmos. Environ.1967, 19.1 (1985): 1-8.

[47] Xu Barringer, Y.S.; Alvarez, V. Cause and prevention of cane molasses gelling. J. Food. Sci. 2005, 70(8):C461-464.

Figure captions

Figure 1. Rainfastness test in young balsam fir

Figure 2. Evaluation of adhesiveness by impregnating needles of balsam fir trees on TSA agar

Figure 3. Btk profile: a) total cell count in SIW and SIW fortified with soybean medium, (b) viable spores count in SIW control and SIW fortified with soybean medium, (c) endotoxin concentration in SIW and SIW fortified with soybean medium

Figure 4. Suspendibility of different formulations: control SIW sorbitol free (C.SIW), SIW only (F.SIW), SIW fortified with soybean medium (F.SIW+ Soya) SIW fortified soybean sorbitol free (C.SIW+Soya), F2d and Foray $76 \mathrm{~B}$ 


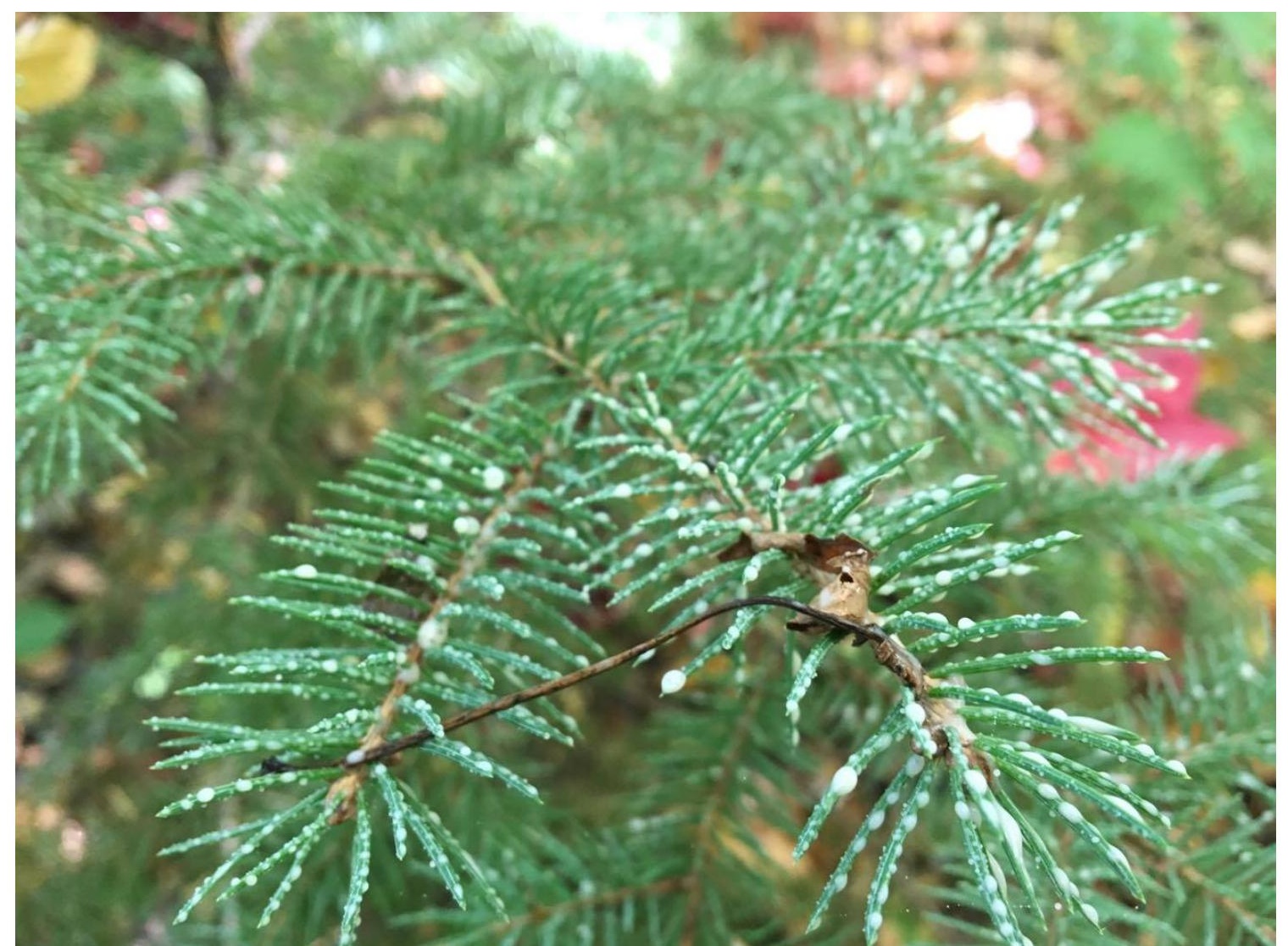


Fig 1.

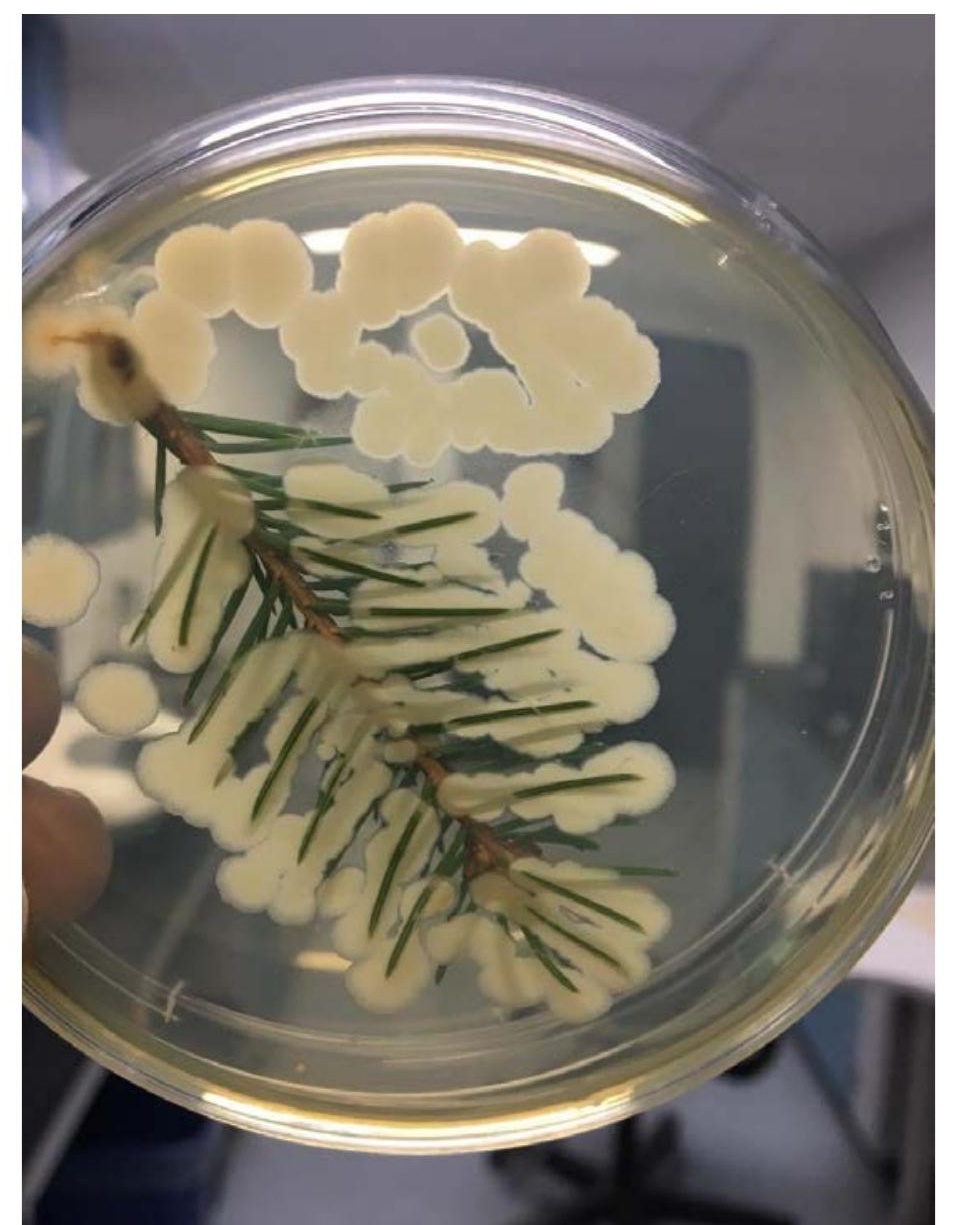


Fig 2.
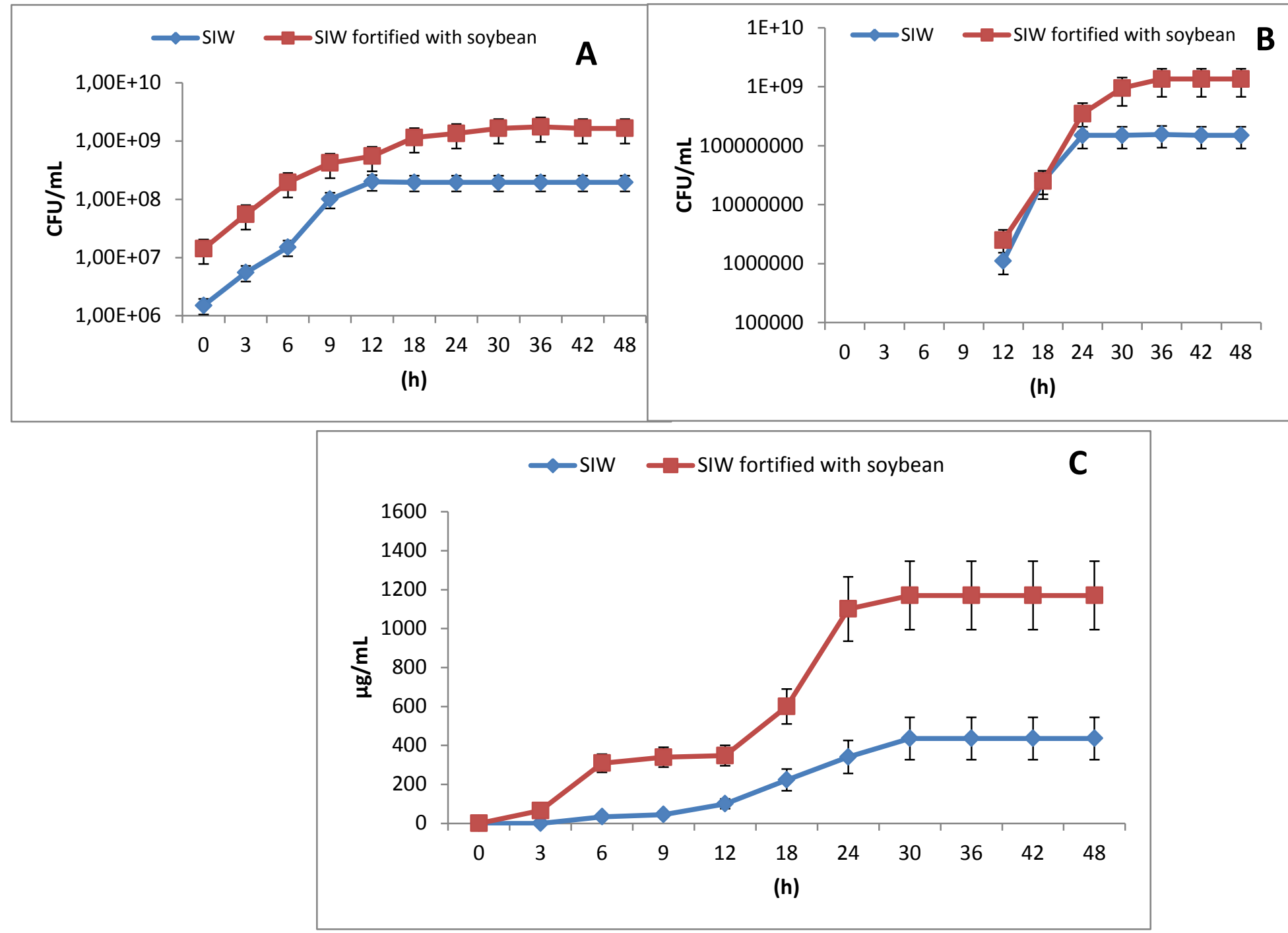

Fig 3. 


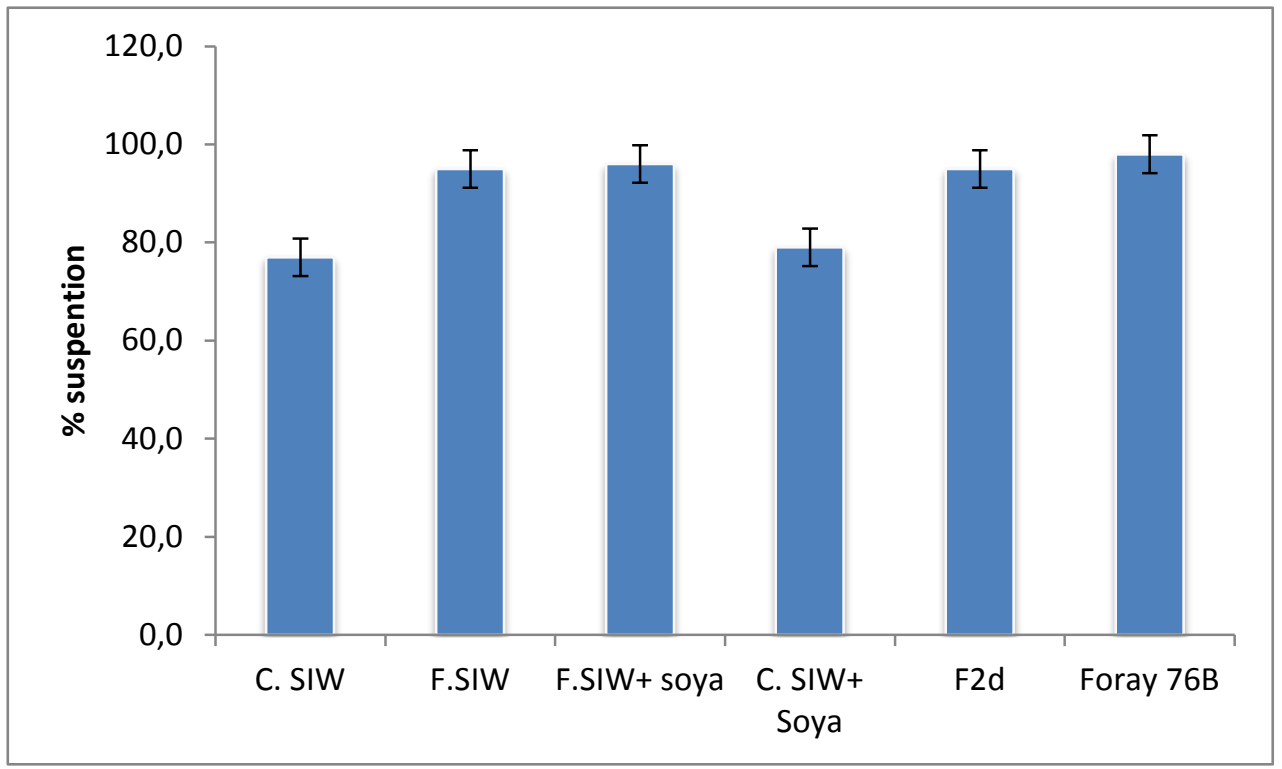

Fig 4. 
Table 1. SIW characteristics-Suggested wavelength and estimated detection limit for minerals selected by ICP-AES axial Vista

\begin{tabular}{|c|c|c|c|}
\hline Minerals & $\begin{array}{l}\text { Suggested wavelength } \\
(\mathrm{nm})\end{array}$ & $\begin{array}{l}\text { Estimated detection limit } \\
(\mathrm{mg} / \mathrm{L})\end{array}$ & Concentrations (mg/L) \\
\hline $\mathrm{AL}$ & 396.152 & 0.0013 & 13 \\
\hline As & 193.696 & 0.0021 & 21 \\
\hline B & 249.678 & 0.0006 & 7 \\
\hline $\mathrm{Ba}$ & 455.403 & 0.0005 & 6 \\
\hline $\mathrm{Ca}$ & 317.933 & 0.0022 & 2.890 \\
\hline $\mathrm{Cd}$ & 214.439 & 0.0001 & $<1$ \\
\hline Co & 238.892 & 0.0003 & $<3$ \\
\hline $\mathrm{Cr}$ & 267.716 & 0.00018 & 5 \\
\hline $\mathrm{Cu}$ & 324.754 & 0.0011 & 11 \\
\hline $\mathrm{Fe}$ & 238.204 & 0.00017 & 100 \\
\hline $\mathrm{K}$ & 766.491 & 0.0016 & 19.500 \\
\hline $\mathrm{Mg}$ & 279.553 & 0.00018 & 5.700 \\
\hline $\mathrm{Mn}$ & 257.610 & 0.00004 & 56.1 \\
\hline Mo & 202.032 & 0.0007 & 8 \\
\hline $\mathrm{Na}$ & 588.995 & 0.0019 & 33.100 \\
\hline $\mathrm{Ni}$ & 231.604 & 0.0007 & 7 \\
\hline $\mathrm{P}$ & 177.434 & 0.003 & 15.800 \\
\hline $\mathrm{Pb}$ & 220.353 & 0.0015 & 15 \\
\hline $\mathrm{S}$ & 181.972 & 0.007 & 6.100 \\
\hline $\mathrm{Sb}$ & 217.582 & 0.003 & 30 \\
\hline Sc & 335.372 & 0.00008 & 5.7 \\
\hline Se & 196.026 & 0.005 & 50 \\
\hline Sn & 189.925 & 0.0018 & 18 \\
\hline $\mathrm{Sr}$ & 407.771 & 0.00017 & 3 \\
\hline $\mathrm{Ti}$ & 337.280 & 0.00011 & 4 \\
\hline V & 292.401 & 0.0004 & 4 \\
\hline $\mathrm{Zn}$ & 206.200 & 0.0004 & 37 \\
\hline \multicolumn{4}{|c|}{ Physical and chemical characteristics } \\
\hline $\begin{array}{l}\text { Total organic carbon } \\
(\mathrm{mg} / \mathrm{L})\end{array}$ & 4990 & & \\
\hline $\begin{array}{l}\text { Total organic nitrogen } \\
(\mathrm{mg} / \mathrm{L})\end{array}$ & 460 & & \\
\hline $\begin{array}{l}\text { Ammonia nitrogen (mg- } \\
\mathrm{N} / \mathrm{L} \text { ) }\end{array}$ & 20.1 & & \\
\hline $\mathrm{pH}$ & 3.5 & & \\
\hline Suspended solids (g/L) & 4.05 & & \\
\hline
\end{tabular}


Table 2: Composition of standard soybean medium and $25 \%$ soybean medium fortified in SIW

\begin{tabular}{|l|l|l|}
\hline Standard soybean medium & $\begin{array}{l}\text { Concentration }(100 \%) \\
\text { g/L }\end{array}$ & $\begin{array}{l}\text { Concentration }(25 \%) \\
\mathrm{g} / \mathrm{L}\end{array}$ \\
\hline CaCO3 & 2 & - \\
\hline FeSO4 & 0.04 & - \\
\hline Glucose & 10 & 2.5 \\
\hline K2HPO4 & 2 & - \\
\hline KH2PO4 & 2 & - \\
\hline MgSO4 & 0.6 & - \\
\hline Soybean flour & 30 & 7.5 \\
\hline Starch & 10 & 2.5 \\
\hline
\end{tabular}


Table 3: Composition of reducing sugars present in SIW control and SIW fortified with synthetic soybean medium by LC-MS-MS.

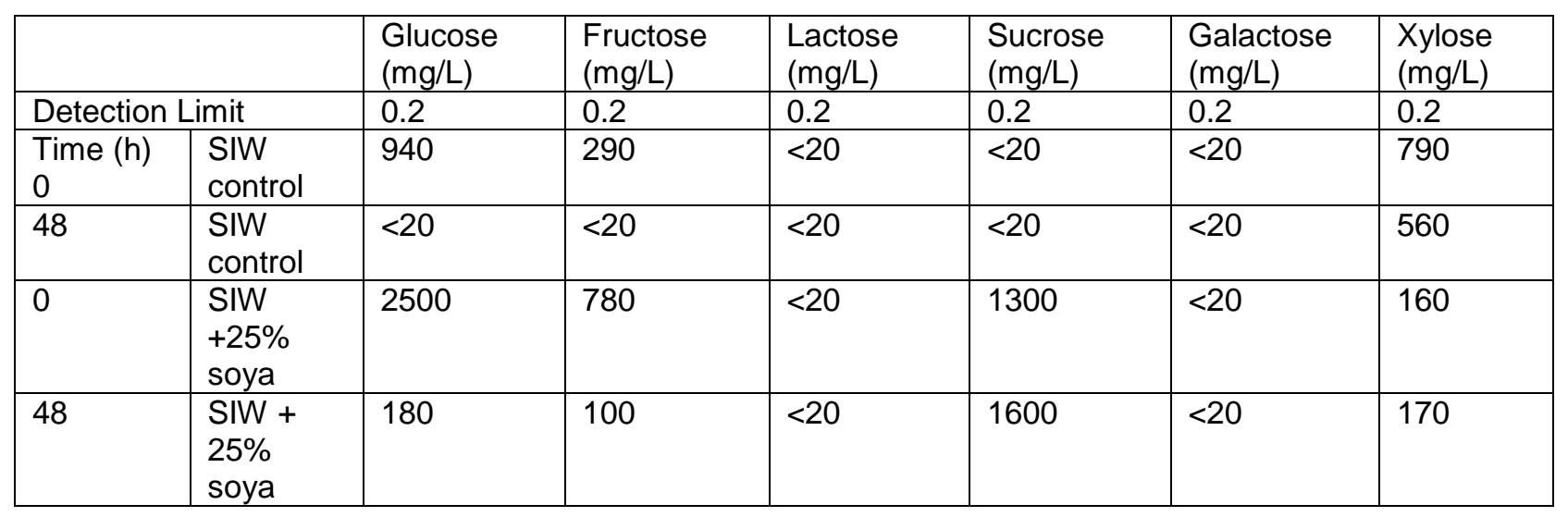


Table 4: Concentration of different adjuvants, viscosity, particle size, zeta potential, total cells count, viable spores count, endotoxin concentration present in different formulations

\begin{tabular}{|c|c|c|c|c|c|}
\hline $\begin{array}{l}\text { Formulation } \rightarrow \\
\text { Adjuvants/suspension } \downarrow\end{array}$ & SIW control & $\begin{array}{l}\text { SIW fortified } \\
\text { with Soybean } \\
\text { medium } \\
(25 \%)\end{array}$ & $\mathrm{F} 2 \mathrm{~d}$ & Foray $76 \mathrm{~B}$ & Btk sander's \\
\hline Cream (L) & 60 & 7 & 6 & - & - \\
\hline Propionic acid (L) & 0.07 & 0.0077 & 0.01 & - & - \\
\hline Sorbitol (Kg) & 1 & 0.11 & 0.13 & - & - \\
\hline Ascorbic acid $(\mathrm{Kg})$ & 0.01 & 0.0011 & 0.13 & - & - \\
\hline $\begin{array}{l}\text { Carboxymethylcellulose } \\
(\mathrm{Kg})\end{array}$ & 0.15 & 0.0055 & 0.018 & - & - \\
\hline Xantham gum $(\mathrm{Kg})$ & 0.2 & 0.0055 & 0.018 & - & - \\
\hline Molasses $(\mathrm{Kg})$ & 0.3 & 0.0165 & 0.03 & - & - \\
\hline Potassium silicate $(\mathrm{Kg})$ & 0.25 & 0.0165 & 0.03 & - & - \\
\hline Sodium acetate $(\mathrm{Kg})$ & 1.7 & 0.0495 & 0.0525 & - & - \\
\hline Acetic acid (L) & 0.25 & 0.0275 & 0.0525 & - & - \\
\hline Fermented Broth (L) & 36 & 4 & 15 & - & - \\
\hline $\begin{array}{l}\text { Total cells count } \\
\text { (CFU/mL) }\end{array}$ & $\begin{array}{l}3.19 \times 10^{9} \\
\pm 0.2552\end{array}$ & $\begin{array}{l}8.3 \times 10^{9} \\
\pm 0.664\end{array}$ & $\begin{array}{l}3.05 \times 10^{9} \\
\pm 0.244\end{array}$ & $\begin{array}{l}4.2 \times 10^{9} \\
\pm 0.336\end{array}$ & $\begin{array}{l}2.45 \times 10^{9} \\
\pm 0.196\end{array}$ \\
\hline $\begin{array}{l}\text { Viable spores count } \\
\text { (CFU/mL) }\end{array}$ & $\begin{array}{l}2.95 \times 10^{9} \\
\pm 0.236\end{array}$ & $\begin{array}{l}7.8 \times 10^{9} \\
\pm 0.624 \\
\end{array}$ & $\begin{array}{l}2.85 \times 10^{9} \\
\pm 0.228\end{array}$ & $\begin{array}{l}3.7 \times 10^{9} \\
\pm 0.296 \\
\end{array}$ & $\begin{array}{l}2.35 \times 10^{9} \\
\pm 0.188\end{array}$ \\
\hline $\begin{array}{l}\text { Endotoxin } \\
(\mu \mathrm{g} / \mathrm{mL})\end{array}$ & \begin{tabular}{|l|}
2951 \\
\pm 147.55 \\
\end{tabular} & $\begin{array}{l}7442 \\
\pm 372.1\end{array}$ & $\begin{array}{l}2850 \\
\pm 142.5\end{array}$ & $\begin{array}{l}3100 \\
\pm 155\end{array}$ & $\begin{array}{l}2500 \\
\pm 125\end{array}$ \\
\hline $\begin{array}{l}\text { Viscosity } \\
\text { cP ou mPas }\end{array}$ & $\begin{array}{l}185 \\
\pm 9.25\end{array}$ & $\begin{array}{l}137 \\
\pm 6.85\end{array}$ & $\begin{array}{l}130 \\
\pm 6.5\end{array}$ & $\begin{array}{l}135 \\
\pm 6.75\end{array}$ & $\begin{array}{l}240 \\
\pm 12\end{array}$ \\
\hline $\begin{array}{l}\text { Particle size } \\
\text { D 50: } \mu \mathrm{m}\end{array}$ & $\begin{array}{l}1.58 \\
\pm 0.1264\end{array}$ & $\begin{array}{l}1.67 \\
\pm 0.1336\end{array}$ & $\begin{array}{l}2.06 \\
\pm 0.1648\end{array}$ & $\begin{array}{l}1.28 \\
\pm 0.1024\end{array}$ & $\begin{array}{l}1.44 \\
\pm 0.1152\end{array}$ \\
\hline Zeta Potential (mV) & $\begin{array}{l}-30 \\
\pm 2.7\end{array}$ & $\begin{array}{l}-35 \\
\pm 3.15\end{array}$ & $\begin{array}{l}-35 \\
\pm 3.15\end{array}$ & $\begin{array}{l}-30 \\
\pm 2.7\end{array}$ & $\begin{array}{l}-35 \\
\pm 3.15\end{array}$ \\
\hline
\end{tabular}


Table 5: Entomotoxicity of different formulation

\begin{tabular}{|l|l|}
\hline Formulation & Entomotoxicity $(\mathrm{IU} / \mu \mathrm{L})$ \\
\hline SIW & $21000 \pm 1680$ \\
\hline SIW fortified with soybean medium & $38000 \pm 3040$ \\
\hline F2d & $21500 \pm 1720$ \\
\hline Btk's sanders & $12500 \pm 1000$ \\
\hline Foray 76B & $20000 \pm 1600$ \\
\hline $\begin{array}{l}\text { SIW } \\
\text { (Fermented broth) }\end{array}$ & $15000 \pm 1200$ \\
\hline $\begin{array}{l}\text { SIW fortified with soybean } \\
\text { (fermented broth) }\end{array}$ & $18000 \pm 1440$ \\
\hline
\end{tabular}


Table 6: Entomotoxicity Half-life of different formulations (Tx 0.5) and Rainfastness test using different formulations

\begin{tabular}{|c|c|c|c|c|c|}
\hline \multicolumn{3}{|c|}{ Substrates } & \multicolumn{3}{|c|}{ Half-life (days) } \\
\hline \multicolumn{3}{|l|}{ SIW } & \multicolumn{3}{|c|}{$10 \pm 0.5$} \\
\hline \multicolumn{3}{|c|}{ SIW fortified soybean } & \multicolumn{3}{|c|}{$12.5 \pm 0.625$} \\
\hline \multicolumn{3}{|c|}{$\mathrm{F} 2 \mathrm{~d}$} & \multicolumn{3}{|c|}{$10 \pm 0.5$} \\
\hline \multicolumn{3}{|c|}{ Btk's sanders } & \multicolumn{3}{|l|}{$6 \pm 0.3$} \\
\hline \multicolumn{3}{|c|}{ Foray 76B } & \multicolumn{3}{|l|}{$7 \pm 0.35$} \\
\hline \multicolumn{3}{|c|}{ SIW fermented broth } & \multicolumn{3}{|l|}{$3 \pm 0.15$} \\
\hline \multicolumn{3}{|c|}{ SIW fortified with soybean medium fermented broth } & \multicolumn{3}{|l|}{$4 \pm 0.2$} \\
\hline \multicolumn{3}{|c|}{ SIW batch centrifuged cream } & \multicolumn{3}{|l|}{$5 \pm 0.25$} \\
\hline \multicolumn{3}{|c|}{$\begin{array}{l}\text { SIW fortified with soybean medium batch } \\
\text { centrifuged cream }\end{array}$} & \multicolumn{3}{|l|}{$6 \pm 0.3$} \\
\hline \multicolumn{6}{|c|}{ Total cell count on balsam fir branch (CFU/mL) } \\
\hline Time & $\mathrm{F} 2 \mathrm{~d}$ & SIW & & $\begin{array}{l}\text { SIW fortified with } \\
\text { soybean medium }\end{array}$ & $\begin{array}{l}\text { Control (adjuvants } \\
\text { in water without } \\
\text { Btk ingredients) }\end{array}$ \\
\hline $1 \mathrm{~h}$ & $>300 \pm 15$ & $>300 \pm 15$ & & $>300 \pm 15$ & $<20 \pm 1$ \\
\hline $24 \mathrm{~h}$ & $>300 \pm 15$ & $>300 \pm 15$ & & $>300 \pm 15$ & $<20 \pm 1$ \\
\hline $48 \mathrm{~h}$ & $220 \pm 11$ & $200 \pm 12$ & & $250 \pm 12.5$ & $<20 \pm 1$ \\
\hline $5 \mathrm{~d}$ & $180 \pm 9$ & $180 \pm 9$ & & $230 \pm 11.5$ & $<20 \pm 1$ \\
\hline $7 \mathrm{~d}$ & $125 \pm 6.25$ & $100 \pm 5$ & & $150 \pm 7.5$ & $<10 \pm 0.5$ \\
\hline
\end{tabular}

